\title{
Evaluation of maternal anemia in tertiary care centre and its neonatal outcomes
}

\author{
Aparna Nair*, Chandana C., Shreedhar Venkatesh, Sampath Kumar
}

\begin{abstract}
Department of Obstetrics and Gynaecology, Vydehi Institute of Medical Sciences and Research Centre, Bangalore,
\end{abstract} Karnataka, India

Received: 03 August 2016

Accepted: 02 September 2016

\section{*Correspondence:}

Dr. Aparna Nair,

E-mail: aparnaarunraj@gmail.com

Copyright: (C) the author(s), publisher and licensee Medip Academy. This is an open-access article distributed under the terms of the Creative Commons Attribution Non-Commercial License, which permits unrestricted non-commercial use, distribution, and reproduction in any medium, provided the original work is properly cited.

\section{ABSTRACT}

Background: Anaemia is the leading cause of maternal mortality and morbidity in India. According to WHO globally, anaemia affects 1.62 billion people. In India, National Family Health Survey 2009, reports that 55\% of women in reproductive age group are anaemic. Maternal anaemia can cause many perinatal complications like low birth weight, preterm delivery, low APGAR score, suboptimal infant breast feeding behavior.

Methods: This prospective study was conducted in Department of OBG at VIMS and RC for a period of 1 year. Of the total 1863 deliveries during this period, only 412 patients meet the inclusion criteria. $\mathrm{Hb} \%<11 \mathrm{gm} \%$ were anaemic and with $\mathrm{Hb} \%>11 \mathrm{gm} \%$ were non anaemic. Haemoglobin estimation was done at time of hospital admission for delivery. Patients background information included education, husband's occupation, monthly family income, urban/rural dwelling. Patients' BMI, obstetric score, number of antenatal visits she has had, if iron tablets taken regularly were all noted. Perinatal parameters recorded were birth weight, gestational age at delivery, perinatal outcome (live birth, intrauterine foetal demise (IUD) and intrauterine growth restriction (IUGR).

Results: Out of the total 412 patients examined, 208 were non-anemic and 204 were anemic. Mean age and B.M.I for anemic and non-anemic women were comparable. Most women in both groups were urban dwellers, attended school up to grade 10, were housewives (35.9) and multi gravidas. There was significant difference in household monthly income and husband's employment in both groups. Majority of patients in both groups had taken $>3$ antenatal checkups, there were significant number of anemic women (15.7\%) who had no A.N.C. checkups. Around $50 \%$ of women in both groups had taken iron tablets irregularly during pregnancy; around $15.7 \%$ and $7.2 \%$ of anemic and non-anemic patients respectively did not take iron tablets at all during pregnancy, though this difference was significant. There was significant difference between the groups regarding knowledge of specific diet plan for ante and post-partum period. Only $16.2 \%$ in anemic and $22.6 \%$ in non-anemic patients knew the correct technique and duration of breast feeding. There is statistically significant increased risk of preterm delivery among anemic women, $27.9 \%$ preterm birth in anemic group and $7.2 \%$ in non-anemic group. Low birth weight was significantly associated with anemic group, also few babies with increased birth weight $>3.5 \mathrm{~kg}$ was seen in anemic group. There were 25 IUGR babies (12.3\%) in anemic and 12 IUGR babies (5.8\%) in non-anemic group, and difference was significant.

Conclusions: In our study we found a positive correlation between maternal anaemia and prematurity, LBW babies, Low APGAR score and PNM. . The knowledge regarding nutritious diet and breast feeding was slightly low among anaemic mothers. This compounds the problem and starts the vicious cycle of anaemic malnourished babies \& mothers.

Keywords: Maternal anemia, Gestational age, Birth weight, Apgar score, Breast feeding 


\section{INTRODUCTION}

Anaemia is the leading cause of maternal mortality and morbidity in India. According to WHO globally, anaemia affects 1.62 billion people, which corresponds to $24.8 \%$ of population. ${ }^{1}$ Worldwide $41.8 \%$ pregnant women are affected. In India, National Family Health Survey 2009, reports that $55 \%$ of women in reproductive age group are anaemic of which $32 \%$ are mild, $15 \%$ is moderate and $3 \%$ is severe. According to NFHS, 59\% pregnant women are anaemic, severe anaemia being highest in Assam and Andhra Pradesh. ${ }^{2}$

Maternal anaemia can cause many perinatal complications like low birth weight, preterm delivery, low APGAR score, suboptimal infant breast feeding behaviour. SIBB in turn starts a vicious cycle in infant leading to decreased weight gain, malnutrition, leading to increased incidence of diarrheal diseases, URTI, otitis media etc., which in turn lead to increase under 5 morbidity and mortality.

India is a developing country where $55 \%$ of female population is anemic. ${ }^{2}$ Anaemia especially due to Iron deficiency is easily preventable and treatable. Government of India supplies IFA (iron and folic acid) tablets free of cost to all pregnant women, in spite of which IDA is rampant. Such complications can be prevented to a large extent by simple correction of $\mathrm{Hb} \%$ during antenatal period. Though often neglected, correct ante partum and post-partum diet plan and regular intake of iron tablets play a crucial role in preventing iron deficiency anaemia in Indian Scenario. Educating and evaluating mother during the time of delivery and immediate post-partum will have long lasting positive impact on health of her children. Many studies have stated that maternal anaemia has no neonatal consequences, as foetus can extract all the nutrition from mother, only maternal complications keeps increasing. The aim of the study was to evaluate the correlation between maternal anaemia and perinatal outcome.

\section{METHODS}

This prospective study was conducted in Department of OBG at Vydehi Institute of Medical Sciences and Research Institute, Banagalore, India from April 2015 to April 2016.Of the total 1863 deliveries during this period, only 411 patients meet the inclusion criteria. The inclusion criteria were singleton pregnancy with no surgical or medical co morbidities, no obstetric complications like placenta previa, or vasa previa, no h/o preterm delivery or cervical incompetence.

Total numbers of patients were divided according to $\mathrm{Hb} \%$. $\mathrm{Hb} \%<11 \mathrm{gm} \%$ were anaemic and with $\mathrm{Hb} \%$ $>11 \mathrm{gm} \%$ were non anaemic. The patients were interviewed when admitted for delivery and data recorded on pre designed questionnaire. Haemoglobin estimation was done at time of hospital admission for delivery by photometric method. Patients background information included education, husband's occupation, monthly family income, urban/rural dwelling. Patients' BMI, obstetric score, number of antenatal visits she has had, if iron tablets taken regularly were all noted. Perinatal parameters recorded were birth weight, gestational age at delivery, perinatal outcome (live birth, intrauterine foetal demise (IUD) and intrauterine growth restriction (IUGR). Gestational age was calculated from first day of last menstrual period. IUGR was defined as the foetal growth (measured by ultrasound) less than the 10th centile for that gestational age. Preterm delivery was defined as delivery after 24 and before 37 completed weeks of gestation. IUD was defined as foetus without cardiac activity, confirmed on ultrasound, at any time after 24 weeks of pregnancy. APGAR score of neonate at 1 and 5 min were recorded. Mother was reviewed after 1 month regarding the health status of the neonate, perinatal mortality and its cause. PNM was defined as death of a foetus after 24 weeks of pregnancy until 1 week after delivery. Patient is asked about her knowledge regarding indigenous iron rich food, any special nutritionally enriched post-partum diet plan, also regarding her knowledge of breast feeding in the questionnaire. On post natal day 1 , both group of patients are counseled bedside regarding healthy diet plan, need for regular intake of iron and calcium tablets till breast feeding continues. Patients are also told benefits of exclusive breast feeding for six months, different techniques and methods to improve lactation.

\section{Statistical analysis}

Descriptive and inferential statistical analysis was carried out in the present study. Student-t test (two tailed, independent) has been used to find the significance of study parameters on continuous scale between two groups (inter group analysis) on metric parameters. Chisquare/fisher exact test has been used to find the significance of study parameters on categorical scale between two or more groups.

\section{RESULTS}

Out of the total 412 patients examined, 208 were non anemic and 204 were anemic. 2 patients went absconding before postnatal counselling could be given. Table 1 shows socioeconomic and demographic details of 2 groups. Mean age and BMI for anemic and non anemic women were comparable. Mean age was 24.16 \pm 4.61 years and $25.05 \pm 5.16$ years respectively for each group and BMI $20.89 \pm 1.79$ and $20.98 \pm 1.85$ respectively for each group. Most women in both groups were urban dwellers. The majority of the women $(70.1 \%$ in the anemic group and $73.5 \%$ in the non-anemic group) had attended school upto grade 10 . Most of the patients in both the groups were housewives $(35.9 \%)$ followed by women of agricultural background (26.9\%). Majority of patients in both groups were multi gravidas. There was significant difference in household monthly income and 
husband's employment in both groups. $51.5 \%$ of anemic pts income range was between 5000-10000 rupees and $64.9 \%$ non anemic patients income range was more than 10000 rupees. $42.8 \%$ of non anemic patient's husbands were in category 5/6 according to kuppuswamy classification for occupation, and in case of anemeic group $39.7 \%$ were category $3 / 4$.

Table 1: Comparison of socioeconomic and demographic details of both groups.

\begin{tabular}{|c|c|c|c|}
\hline Maternal information & $\begin{array}{l}\text { Anemic group n } \\
=204\end{array}$ & Non anemic group $n=208$ & $\begin{array}{l}\text { p value }<0.05 \text { is } \\
\text { significant }\end{array}$ \\
\hline Age (mean \pm S.D.) & $24.16 \pm 4.61$ years & $25.05 \pm 5.16$ years & 0.100 \\
\hline B.M.I.(mean \pm S.D) & $20.89 \pm 1.79$ & $20.98 \pm 1.85$ & 0.599 \\
\hline $\begin{array}{l}\text { Educational status } \\
\text { Upto } 10^{\text {th }} \\
\text { More than } 10^{\text {th }}\end{array}$ & $\begin{array}{l}143(70.1 \%) \\
61(29.9 \%)\end{array}$ & $\begin{array}{l}153(73.5 \%) \\
55(26.5 \%)\end{array}$ & 0.864 \\
\hline $\begin{array}{l}\text { Employment status } \\
\text { House wife } \\
\text { Labour worker } \\
\text { Agricultural back ground } \\
\text { Shop worker }\end{array}$ & $\begin{array}{l}72(35.3 \%) \\
35(17.2 \% \\
56(27.5 \%) \\
41(20.1 \%)\end{array}$ & $\begin{array}{l}76(36.5 \%) \\
47(22.6 \%) \\
55(26.4 \%) \\
30(14.4 \%)\end{array}$ & 0.316 \\
\hline $\begin{array}{l}\text { Husband's employment } \\
\text { Unemployed } \\
\text { Unskilled } \\
\text { Semiskilled } \\
\text { Clerical/shop owner/farmer } \\
\text { Semi-professional } \\
\text { professional }\end{array}$ & $\begin{array}{l}5(2.5 \%) \\
21(10.3 \%) \\
53(26 \%) \\
81(39.7 \%) \\
44(21.6 \%) \\
0(0 \%)\end{array}$ & $\begin{array}{l}1(0.5 \%) \\
17(8.2 \%) \\
30(14.4 \%) \\
71(34.1 \%) \\
78(37.5 \%) \\
11(5.3 \%)\end{array}$ & $<0.001 * *$ \\
\hline $\begin{array}{l}\text { Monthly income } \\
\text { Less than Rs } 5000 \\
\text { Rs 5000-10000 } \\
\text { More than } 10000\end{array}$ & $\begin{array}{l}27(13.2 \%) \\
105(51.5 \%) \\
72(35.3 \%)\end{array}$ & $\begin{array}{l}16(7.7 \%) \\
57(27.4 \%) \\
135(64.9 \%)\end{array}$ & $<0.001 * *$ \\
\hline $\begin{array}{l}\text { Region of residence } \\
\text { Rural } \\
\text { Urban }\end{array}$ & $\begin{array}{l}89(43.6 \%) \\
115(56.4 \%)\end{array}$ & $\begin{array}{l}79(38 \%) \\
129(62 \%)\end{array}$ & 0.244 \\
\hline $\begin{array}{l}\text { Obstetric score } \\
\text { Primis } \\
\text { Multigravida }\end{array}$ & $\begin{array}{l}76(37.3 \%) \\
128(62.7 \%)\end{array}$ & $\begin{array}{l}99(47.6 \%) \\
109(52.4 \%)\end{array}$ & $0.034 *$ \\
\hline $\begin{array}{l}\text { Antenatal check-ups } \\
\text { none } \\
\text { less than } 3 \\
\text { more than } 3\end{array}$ & $\begin{array}{l}66(32.4 \%) \\
106(52 \%)\end{array}$ & $\begin{array}{l}12(5.8 \%) \\
68(32.7 \%) \\
126(60.6 \%)\end{array}$ & $\mathrm{P}=0.004 * *$ \\
\hline $\begin{array}{l}\text { Iron tablets consumed during pregnancy } \\
\text { none } \\
\text { irregular } \\
\text { regular }\end{array}$ & $\begin{array}{l}32(15.7 \%) \\
102(50 \%) \\
65(31.9 \%)\end{array}$ & $\begin{array}{l}15(7.2 \%) \\
108(51.9 \%) \\
85(40.9 \%)\end{array}$ & $\mathrm{P}=0.012^{*}$ \\
\hline $\begin{array}{l}\text { Diet plan } \\
\text { yes } \\
\text { no }\end{array}$ & $\begin{array}{l}106(52 \%) \\
98(48 \%)\end{array}$ & $\begin{array}{l}129(62 \%) \\
79(38 \%)\end{array}$ & $0.039 *$ \\
\hline $\begin{array}{l}\text { Breast feeding awareness } \\
\text { yes } \\
\text { no }\end{array}$ & $\begin{array}{l}33(16.2 \%) \\
171(83.8 \%)\end{array}$ & $\begin{array}{l}47(22.6 \%) \\
161(77.4 \%)\end{array}$ & 0.100 \\
\hline $\begin{array}{l}\text { Counseling } \\
\text { yes } \\
\text { no }\end{array}$ & $\begin{array}{l}203(99.5 \%) \\
1(0.5 \%)\end{array}$ & $\begin{array}{l}207(99.5 \%) \\
1(0.5 \%)\end{array}$ & 0.989 \\
\hline
\end{tabular}

Though majority of patients in both groups had taken $>3$ antenatal checkups, there were significant number of anemic women $(15.7 \%)$ who had no ANC checkups at all. Around $50 \%$ of women in both groups had taken iron 
tablets irregularly during pregnancy; around $15.7 \%$ and $7.2 \%$ of anemic and non anemic patients respectively did not take iron tablets at all during pregnancy, though this difference was significant.

$52 \%$ of anemic women and $62 \%$ of non anemic women responded positively regarding knowledge of specific diet plan for ante and post-partum period and difference was statistically significant. Only $16.2 \%$ in anemic and $22.6 \%$ in non anemic patients knew the correct technique and duration of breast feeding.

Table 2 outlines the analysis of perinatal outcomes in the two groups. There is statistically significant increased risk of preterm delivery among anemic women, $27.9 \%$ preterm birth in anemic group and $7.2 \%$ in non anemic group.

Table 2: Perinatal outcome of 2 groups.

\begin{tabular}{|llll|}
\hline Variable & Anemic & Non anemic & P-value \\
\hline Preterm birth & $57(27.9 \%)$ & $15(7.2 \%)$ & \\
Yes & $147(72.1 \%)$ & $193(92.8 \%)$ & $<0.001^{* *}$ \\
No & Mean G.A $=37.62 \pm 2.15$ & Mean G.A $=38.57 \pm 1.65$ & \\
\hline Low birth weight & & & \\
Yes & $56(27.5 \%)$ & $21(10.1 \%)$ & P=0.002** \\
No & $148(72.6 \%)$ & $187(89.9 \%)$ & \\
\hline IUGR & $25(12.3 \%)$ & $12(5.8 \%)$ & \\
Yes & 179 & 196 & 0.170 \\
No & $4(2 \%)$ & $1(0.5 \%)$ & \\
\hline Perinatal mortality & 200 & 207 & $0.058+$ \\
Yes & & $11(5.3 \%)$ & \\
No & $21(10.3 \%)$ & $197(94.7 \%)$ & 0.489 \\
\hline Low APGAR at 1 min & $183(89.7 \%)$ & $10(4.8 \%)$ & \\
Yes & & $198(95.2 \%)$ & \\
No & $13(6.4 \%)$ & & \\
\hline Low APGAR at 5 min & $191(93.6 \%)$ & & \\
Yes & & & \\
No & & & \\
\hline
\end{tabular}

There were two observations in terms of birth weight, low birth weights was significantly associated with anemic group, also few babies with increased birth weight $>3.5 \mathrm{~kg}$ was seen in anemic group as depicted in Table 3.

Table 3: Birth weight distribution in both groups.

\begin{tabular}{|c|c|c|c|}
\hline $\begin{array}{l}\text { Birth } \\
\text { weight } \\
\text { (kg) }\end{array}$ & $\begin{array}{l}\text { Anemic } \\
(\mathrm{Hb}<11 \mathrm{gm} \%)\end{array}$ & $\begin{array}{l}\text { Non anemic } \\
(\mathrm{Hb}>11 \mathrm{gm} \%)\end{array}$ & Total \\
\hline$<2.5$ & $56(27.5 \%)$ & $21(10.1 \%)$ & $\begin{array}{l}77 \\
(18.7 \%)\end{array}$ \\
\hline $2.5-3.5$ & $146(71.6 \%)$ & $187(89.9 \%)$ & $\begin{array}{l}333 \\
(80.8 \%)\end{array}$ \\
\hline$>3.5$ & $2(1 \%)$ & $0(0 \%)$ & $2(0.5 \%)$ \\
\hline Total & $204(100 \%)$ & $208(100 \%)$ & $\begin{array}{l}412 \\
(100 \%)\end{array}$ \\
\hline Mean \pm SD & $2.72 \pm 0.61$ & $2.89 \pm 0.42$ & $\begin{array}{l}2.80 \pm 0.5 \\
3\end{array}$ \\
\hline
\end{tabular}

$\mathrm{p}=0.002 * *$, significant, Student $\mathrm{t}$ test

There were 25 IUGR babies (12.3\%) in anemic and 12 IUGR babies $(5.8 \%)$ in non anemic group and difference was significant. There 5 perinatal mortality cases, 4 occurred in anaemic group and 1 in non-anemic group and the difference was not significant. Low APGAR score at $1 \mathrm{~min}$ were seen in 21 and 11 babies of anemic and non anemic group respectively. At 5 min 13 and 10 babies of anemic and non anemic group had low APGAR score respectively.

It was not a significant difference. Post-partum counselling was given to all patients on 1st post-partum day except one in each group who left hospital immediately after delivery.

\section{DISCUSSION}

Of the 7.3 million perinatal deaths occurring globally, majority occur in Asia and anaemia is the leading cause of maternal mortality and morbidity in Asia. It could be concurred that correction of anaemia may prevent a bulk of these.

Anaemia is a rampant disease, but perinatal outcome depends on type and severity of anaemia. Duthie et al have demonstrated differences in outcomes between iron 
deficiency and physiological anaemia of pregnancy. The risk of prematurity and LBW is higher in anaemic women. According to Whittaker et al. in populations in which the rate of anaemia is low among non-pregnant women, the primary cause of anaemia during pregnancy is likely to be plasma volume expansion (physiological anaemia of pregnancy) and this anaemia is not associated with negative birth outcomes. LBW is both associated with severe anaemia and high $\mathrm{Hb} \%$ values, having a $\mathrm{U}$ shaped relationship. Malhotra $\mathrm{M}$ et al concluded that the mean birth weight was maximum in the 9.6-10.5 gm\% category and that it fell with both increasing and decreasing hemoglobin values, being lowest with severe anaemia. ${ }^{4}$ Mild anemia fared best in maternal and perinatal outcome. In a similar study conducted by Jagdish et al found that mean birth weight of babies born to anaemic mothers were marginally lower that nonanaemic mothers. Though according to Cardich MR et al infants of mothers with anaemia had higher hemocrit compared to those born to non anaemic mothers at high altitudes. ${ }^{6}$ Levy A et al did a multivariable analysis and found higher rate of preterm deliveries ( $<37$ weeks gestation) and low birth weight $(<2500 \mathrm{~g})$ were found among patients with anaemia as compared to the nonanaemic women $(10.7 \%$ versus $9.0 \%, \mathrm{p}<0.001$ and $10.5 \%$ versus $9.4 \%, \mathrm{p}<0.001$; respectively), similar to the present study. ${ }^{7}$ According to Mahamuda et al there is significant difference in apgar score of infants born to anaemic and non anaemic mothers. ${ }^{8}$

Hooton et al stated that the relationship of anaemia and infections may be due to adverse effect on immune function, by altering the proliferation of $\mathrm{T}$ and $\mathrm{B}$ lymphocytes, reducing the bactericidal activity of phagocytes and neutrophils. ${ }^{9}$ Consequently the complication of preterm labour and pregnancy related infections has also been shown to have a causal relationship with each other.

Factors like gender bias, low income resources and lack of knowledge about the importance of intake of balanced and iron-rich diet contribute to anemia, rendering it a continuing challenge for change and intervention at an early age in women. The high prevalence of iron and other micro-nutrient deficiencies among women before and during pregnancy calls for interventions such as periodic supplementation and effective education regarding diet and family planning. This may help to reduce iron deficiency, improve public health and thus reduce maternal morbidity and mortality.

Effect of anaemia on mother could not be assessed in this study. Secondly if other micronutrient deficiencies have similar perinatal outcome could be studied and evaluated to reduce the confounding effect.

\section{CONCLUSION}

A positive correlation between maternal anaemia and prematurity, LBW babies, Low APGAR score and PNM was found. Most common cause of PNM was prematurity. The knowledge regarding nutritious diet and breast feeding was slightly low among anaemic mothers. This compounds the problem and starts the vicious cycle of anaemic malnourished babies and mothers. The improvements achieved in the developed world are due largely to more effective diagnosis and treatment. Post natal councilling was given to all the patients regarding regular iron intake and iron rich food to prevent further deterioration of body iron status. Women have to be made aware of the iron content in a balanced diet, especially in green leafy vegetables and regular iron supplementation during ante partum and post-partum period. Iron stores of the infant are built up during third trimester and lactation. Diarrheal diseases of new born can be prevented to a large extent by exclusive breast feeding. Both these in turn help in preventing infection, by improving immunity during early childhood. Hence knowledge regarding breast feeding is critical to be assessed and correct knowledge imparted. Council ling plays an important role in reducing adverse pregnancy outcome.

Funding: No funding sources

Conflict of interest: None declared

Ethical approval: The study was approved by the Institutional Ethics Committee

\section{REFERENCES}

1. WHO. Available at www.who.int /vmnis/ anaemia/prevalance/summary/anaemia_data_status_t 2/en/official who website. Accessed on 13 May 2016.

2. Nutrition in India. Available at www.rchiips.org/nfhs/nutrition_report_for_website_ 18sep09.pdf. Accessed on 15 May 2016.

3. Duthie SJ, King PA, To WK, Lopes A, Ma HK. A case controlled study of pregnancy complicated by severe maternal anemia. Australian New Zealand Journal Obstetrics Gynaecology. 1991;31:125-7.

4. Malhotra M, Sharma JB. Maternal and perinatal outcome in varying degrees of anemia. Int J Gynea Obstetrics. 2002;79(2);93-100.

5. Jagadish K, Asha N. Maternal anaemia in various trimesters and its effect on newborn weight and maturity. observational study. Int J Preventive Medicine. 2013;4(2):193-9.

6. Maria E, Cardich R, Saito M, Gilman RH, Escate LE, John J, Strouse et al. Effect of maternal anemia at high altitude on infant hematocrit and oxygenation. Am J Tropical Med Hygiene. 2004;70(4):420-4.

7. Levy A, Fraser D. Maternal anaemia during pregnancy is an independent risk factor for low birth weight and preterm delivery. European J Obstet Gyne Reproductive Bio. 2005;122:182-6.

8. Mahamuda B, Tanira S, Feroza W, Perven HA, Shamim A. Effects of maternal anaemia on neonatal outcome a study done in the specialized urban 
hospital set up in Bangladesh. Bangladesh J Med Sci. 2011;10(3):177-80.

9. Hooton TM, Scholes D, Hughes JP, Winter C. A prospective study of risk factors for symptomatic urinary tract infection in young women. New England Journal of Medicine. 1996;335:468-74.
10. Kumar P, Pore P. Maternal anaemia and its impact on perinatal outcome in tertiary care hospital of Pune, Maharashtra. Indian J Basic Applied Med Res. 2012;2(1):111-9.

Cite this article as: Nair A, Chandana C, Venkatesh $\mathrm{S}$, Kumar S. Evaluation of maternal anemia in tertiary care centre and its neonatal outcomes. Int $\mathbf{J}$ Reprod Contracept Obstet Gynecol 2016;5:3506-11. 